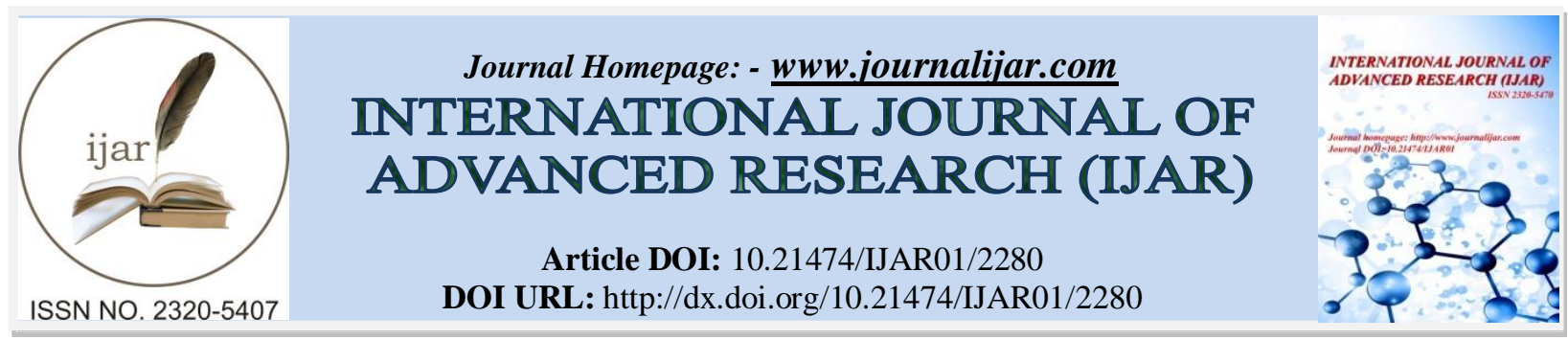

RESEARCH ARTICLE

\title{
ASSOCIATION BETWEEN DEMOGRAPHIC FACTORS AND SAVING OF STATE SECTOR EMPLOYEES IN KARAVEDDY DIVISIONAL SECRETARIAT DIVISION IN JAFFNA DISTRICT - SRI LANKA.
}

Subramaniam, V.A.

Senior Lecturer, Department of Financial Management, University of Jaffna, Sri Lanka.

\section{Manuscript Info}

Manuscript History

Received: 29 September 2016

Final Accepted: 30 October 2016

Published: November 2016

Key words:-

Income, Saving, Demographic factors.

\section{Abstract}

Unspent income is called as saving and it plays an important role in maintaining proper standard of living of households and providing necessary capital for an economy which is essential for economic development. This study aims to identify the association between demographic factors and the saving of the state sector employees in the Karaveddy Divisional Secretariat Division in Jaffna District of Sri Lanka. Karaveddy Divisional Secretariat is one of the Divisional Secretariat under the Jaffna District Secretariat in Northern Province of Sri Lanka. The necessary data for the study were collected through questionnaire from 144 state sector employees and the respondents were selected under simple random sampling method. The Chi-square test was used to identify the association between demographic factors and saving. It was concluded that age, civil status, educational qualification and income have association with saving of the state sector employees in the Karaveddy Divisional Secretariat, whereas author couldn't find any association between gender and family size; and saving. Based on these findings, it is recommended that Governmental authorities, banks and financial institutions should introduce different categories of investment and saving programs and projects for different group of state sector employees.

Copy Right, IJAR, 2016,. All rights reserved.

\section{Introduction:-}

A person can allocate a part of his income for consuming goods and services with the objective of satisfying various current needs of him. The remaining unspent part of his income can be saved for the purpose of satisfying his future needs. According to McConnell and Brue (1999) personal saving is the part of income that is not used to pay taxes or to purchase consumer goods and services, but which flows into various investment avenues. Thus income can be considered as the fundamental source for saving and the income may arise in the forms of salary or wages, profit from business or trade, corporate profit or dividend, interest payments and earning from agriculture. Similarly consumption may be in the forms of expenditure on food, clothing, housing, rent, health, education, utilities, traveling, festivals, ceremonies, recreation and charities.

Saving provides various benefits to households, institutions, regions and nations. Saving is considered as an integral aspect in the life of individuals. It can be viewed as a way of reducing the risk of uncertain future. Since it is very difficult to predict the future, individuals need to face their future with the support of their savings. In other words, 
saving is the only way for creating financial security for households. Particularly, individuals need to consider their own financial security after retirement.

Capital investments in various sectors of an economy is very essential for growth of the economy and national savings provide the necessary foundation for the capital investments. According to Schmidt-Hebbel, Serven, \& Solomano (1996) there is a positive relationship between saving and economic growth of nations. Similarly, Solow (1956) indicated that higher saving rate plays a key role in achieving a higher growth in per capita capital and per capita income. National savings include private savings, public savings and foreign savings. Household savings and corporate savings are the two major elements of private savings and household savings play a significant role in private savings. Public savings mean the savings by the government. Household saving is the important domestic source of funds for capital investment. Due to this reason mobilization of household savings is viewed as a prerequisite for economic growth. Nurkse (1953) argued that lower level of capital accumulation is the reason for the under development condition of the less developed countries. Thus at present, developing countries provide more attention for mobilizing domestic savings in order to achieve economic growth.

Theoretically the Absolute Income Hypothesis (Keynes, 1936), the Life-Cycle Hypothesis (Modigliani and Brumberg, 1954) and the Permanent Income Hypothesis (Friedman, 1957) explain the consumption and saving decisions of people. Absolute Income Hypothesis explains the association between income and consumption as well as between income and savings. According to the Life-Cycle Hypothesis among young and old households the average propensity to consume is higher and at the same time propensity to save is lower. However households in middle age tend to have higher incomes with lower propensity to consume and higher propensity to save. In short, households in middle age have higher wealth and accumulated savings and thus the age of the households play an important role in the saving behavior. According to Permanent Income Hypothesis both permanent and transitory income as well as current level of wealth determine saving.

\section{Research Problem:-}

At present households and Governments provide more emphasis for saving. It is very essential for household for ensuring financial security in their life. Similarly, Governments use saving as a tool for economic development. In this background various studies were carried out to identify the determinants of saving. Attanasio (1997) found a negative association between age of household and saving whereas, Khalek, Arestoff, De-Freitas \& Mage (2009) failed to observe any association between age and saving. Furthermore, Jamal, Hanif \& Mushtaq (2014) identified positive relationship between level of education of household head and income; and saving. However, Burey and Khan (1992) concluded that education have negative influence on household savings. Therefore, this study attempts to identify the association between demographic factors and the saving of the state sector employees in the Karaveddy Divisional Secretariat Division in Jaffna District of Sri Lanka.

\section{Objectives of the Study:-}

The objective of the study is to identify the association between demographic factors and the saving of the state sector employees in the Karaveddy Divisional Secretariat Division in Jaffna District of Sri Lanka.

\section{Significance of the Study:-}

Higher level of saving offers various benefits to households, regions and nations. For households it provides better standard of living and financial security for their life. Similarly, through capital accumulation it supports the regional and national development. In this background the findings of the study will support to identify the ways to promote the standard of living of the Government employees in the study area. In addition, the findings will also support the Government and local authorities such as Northern Provincial Council, Jaffna District secretariat and Karaveddy Divisional Secretariat in designing policies to promote savings and capital accumulation for the purpose of national and regional developments.

\section{Review of Literature:-}

Lahiri (1989) found that private saving depends on the rate of growth of personal disposable income. In addition, Schrooten and Stephan (2005) concluded that per capita income has positive effect on saving. Schmidt-Hebbel, Webb \& Corsetti (1992) concluded that there is a positive association between income and household saving. Huberman, Iyengar \& Jiang (2007) argued that low income group of people heavily rely on public pension systems for their retirement income and due to this reason they fail to save. 
Li, Montalto \& Geistfeld (1996) observed that married persons exhibit more interest on their wealth and savings.

Bovenberg and Evant (1990) mentioned that the higher the old aged population in an economy the lower is the saving rate in the economy. Similarly, Attanasio (1997) proved that there is a negative association between age of household and the saving and it implies that the older people saves less and the younger people save more. Further, Demery and Duck (2006) found that saving rates are corresponding to the life-cycle model and authors also indicated that people in the working life tend to show more interest on savings when they reach the age of 50 years.

Higher level of education of households support to increase their personal income as well as savings by increasing human productivity and capabilities (Zhang, Zhang \& Lee, 2003). Similarly, Browning and Lusardi (1996) indicated that higher level of financial literacy of people leads to higher level of saving. Brata (1999) found that education have positive impact on savings and he also observed that males tend to save more than females.

Muradoglu and Taskin (1996) indicated that self employed household exhibits regular and consistent saving behaviour due to the fear of their uncertain future.

Newman, Tarp, Broeck, Quang and Khai (2008) conducted a survey among 2324 households in Vietnam and found that wealthier households tend to save more and age of household head has negative impact on saving. furthermore, education has no effect.

Khalek, Arestoff, De-Freitas \& Mage (2009) made an attempt to identify the determinants of household saving in Morocco and concluded that household income has positive influence on saving, however, household size has negative impact on household saving. In addition, authors could not observe any significant impact of age on household savings.

Bautista and Lamberte (1990) investigated the saving behavior of rural and urban households in the Philippines by surveying 16971 respondents. Authors concluded that income has positive impact on household saving, whereas, dependency ratio has negative impact.

Jamal, Hanif \& Mushtaq (2014) found that level of education of household head and income have positive association with household saving.

Burey and Khan (1992) found that education have negative effect on household savings, whereas, occupation of household has no influence on savings. In addition, household savings increase with age but tend to decline when age crosses a certain limit.

Ur Rehman, Faridi \& Bashir (2010) surveyed 293 household respondents in Pakistan and found that income of household is positively related with household savings, however, level of education of household head and marital status are negatively associated with saving of households.

\section{Profile of the Study Area:-}

The study aims to identify the association between demographic factors and the savings of state sector employees in the Karaveddy Divisional Secretariat in Sri Lanka. Karaveddy Divisional Secretariat is one of the Divisional Secretariat under the Jaffna District secretariat in Northern Province of Sri Lanka. It is also called as Vadamarachchi South West Divisional Secretariat. This Divisional Secretariat covers an area of 88.00 Sq.Km and there are 35 Grama Niladari Divisions under Karaveddy Divisional Secretariat. 14,594 families live in this Divisional Secretariat and the total population is 45,530 . Among the total population $47.9 \%$ are males and $52.1 \%$ are females.

\section{Research Methodology:- \\ Data Type and Source;-}

Primary and secondary sources were used in this study. The relevant statistics about the study area were obtained from various reports and statistical hand books. In addition, the association between demographic factors and the savings of state sector employees in the Karaveddy Divisional Secretariat was examined by using the data collected from the state sector employees in the study region through a questionnaire. 


\section{Sampling Design:-}

The population of the study is the state sector employees in the Karaveddy Divisional Secretariat and the total number of population is 2455 . The study used simple random sampling technique to select the sample from the population. Due to the homogeneity characteristics of the respondents and the availability of the details of these population in the registers of the Karaveddy Divisional Secretariat researcher decided to apply this technique.150 questionnaires were issued and among them 144 were collected in a usable form.

\section{Research Model:-}

In this study saving of the state sector employees is considered as dependent variable and it is measured in terms of quarterly saving amount of respondents. Sex, age, civil status, educational qualification, family size and income are considered as independent variables.

\section{Data Analysis Techniques:-}

The study utilized percentage analysis and Chi-square test and Chi-square test was used to identify the association between demographic factors and saving.

\section{Profile of Respondents:-}

The demographic profile of the respondents of the study are shown in Table 1.

Table 1:- Profile of Respondents.

\begin{tabular}{|c|c|c|c|}
\hline \multicolumn{2}{|c|}{ Demographic Factors } & Number of Respondents & Percentage \\
\hline Gender & Male & 76 & 52.8 \\
\hline Age & Female & 68 & 47.2 \\
\hline & $20-30$ Years & 26 & 27.1 \\
\hline & $31-40$ Years & 39 & 25.7 \\
\hline & $41-50$ Years & 37 & 18.0 \\
\hline Civil Status & $51-60$ Years & 26 & 31.1 \\
\hline & $>60$ Years & 16 & 68.7 \\
\hline Educational & Single & 45 & 16.7 \\
Qualification & Married & 99 & 38.2 \\
\hline & G.C.E.O/L & 24 & 36.1 \\
\hline & G.C.E. A/L & 55 & 9.0 \\
\hline & Graduate & 52 & 20.8 \\
\hline Family Size & Post Graduate & 13 & 47.3 \\
\hline & $<3$ Members & 30 & 21.5 \\
\hline & $3-4$ Members & 68 & 10.4 \\
\hline & $5-6$ Members & 31 & 18.8 \\
\hline Monthly Income & $>6$ Members & 15 & 31.9 \\
\hline (Rs) & $<25000$ & 27 & 22.9 \\
\hline & & & 18.1 \\
\hline & $25000-35000$ & 46 & 8.3 \\
\hline & $35001-45000$ & 33 & \\
\hline & $45001-55000$ & 26 & 12 \\
\hline
\end{tabular}

Table 1 reveals that $52.8 \%$ of the respondents are males and $47.2 \%$ of them are females. $52.8 \%$ of the respondents are within the age range from 31 years to 50 years. Similarly, $68.7 \%$ of them are married and $31.9 \%$ of respondents earn a monthly income which is in the range from 25000 to 35000 .

\section{Analysis and Interpretation:-}

\section{Analysis of Amount of Saving;-}

The distribution of respondents based on the quarterly saving amount of them are shown in the table 2 and figure 1. 
Table 2:- Distribution of Respondents based on Quarterly Saving Amount

\begin{tabular}{|l|c|c|}
\hline Quarterly Saving Amount (Rs) & Number of Respondents & Percentage \\
\hline$<10,000$ & 59 & 41.0 \\
\hline $10,000-20,000$ & 50 & 34.7 \\
\hline $20,001-30,000$ & 29 & 20.1 \\
\hline$>30,000$ & 06 & 04.2 \\
\hline Total & 144 & 100.0 \\
\hline
\end{tabular}

Figure 1:- Distribution of Respondents based on Quarterly Saving Amount

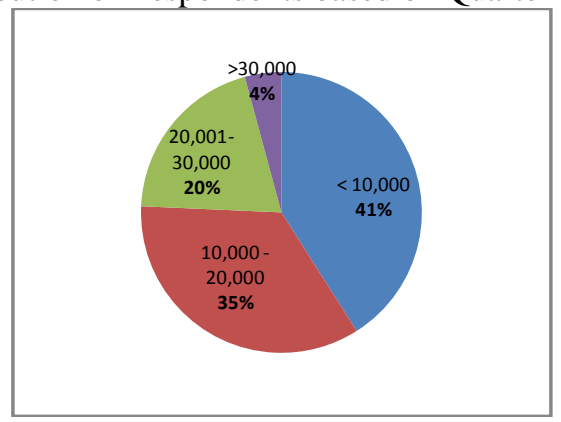

According to the table 2, majority of the respondents (41\%) save less than 10000 Rupees in a quarter. Further $75.7 \%$ of them save less than 20000 Rupees whereas, only $4.2 \%$ of respondents are able to save more than 30000 Rupees in a quarter.

\section{Association between Demographic Factors and Saving;-}

The results of Chi-Square test conducted to find out association between demographic factors and saving shown in the table 3 .

Table 3:- Relationships between Demographic Factors and Saving.

\begin{tabular}{|c|c|c|c|l|}
\hline Demographic factors & $\begin{array}{c}\text { Pearson Chi- } \\
\text { Square } \\
\text { Value }\end{array}$ & df & $\begin{array}{c}\text { Asymp. Sig. (2- } \\
\text { sided) }\end{array}$ & Sig or Not sig \\
\hline Gender & 1.008 & 3 & 0.799 & Not Significant \\
\hline Age & 29.717 & 12 & 0.003 & Significant \\
\hline Civil Status & 9.875 & 3 & 0.020 & Significant \\
\hline Educational Qualification & 24.643 & 9 & 0.003 & Significant \\
\hline Family size & 9.171 & 9 & 0.422 & Not Significant \\
\hline Income & 39.658 & 12 & 0.000 & Significant \\
\hline
\end{tabular}

According to the results of the Chi-Square test there is no significant relationship between gender of respondents and saving. However, age of the state sector employees has a significant association with saving. It is consistent with the findings of Burey and Khan (1992) and at the beginning stage of the career of the state sector employees, they provide more importance for satisfying some of their needs such as need for a home and need for a car. Normally they purchase these assets by using loans or leasing schemes. Thus in this stage due to these installment payments their relative savings are low. However, when they reach the middle part of their career, they are able to settle their liabilities in full and their savings are high.

Furthermore, civil status of the respondents also shows a significant relationship with saving. This finding is in agreement with the finding of Li, Montalto \& Geistfeld (1996) and married people exhibit more interest on saving than single persons. In addition, educational qualification of government employees has a significant relationship with saving. The studies conducted by Teshome, Kassa, Emana, \& Haji (2013) and Jamal, Hanif \& Mushtaq (2014) also confirmed the role of educational qualification in saving. Higher educational qualification may help to improve the financial literacy and the level of awareness on importance of saving. 
The results of the Chi-Square test reveals that there is no significant association between family size of the respondents and saving. However, it is inconsistent with the findings of Khalek, Arestoff, De-Freitas \& Mage (2009) and Ur Rehman, Faridi \& Bashir (2010) who concluded that there is a negative association between family size and saving. The main reason for this situation is that most of the families in the study region are with small family size. $68 \%$ of the respondents have four or less than four members in their family. In addition, most of the state sector employees in the study area has their own paddy fields and engage in the paddy cultivation for the purpose of satisfying their own family needs. Thus an increase in the family size will not result in a higher increase in the food expenditure of the family.

Finally, income of the state sector employees has a significant relationship with saving. This is consistent with the Absolute Income Hypothesis of Keynes and the findings of Jamal, Hanif \& Mushtaq (2014) and Ur Rehman, Faridi \& Bashir (2010). Actually income can be considered as a source for saving.

\section{Conclusion:-}

The objective of this study is to identify the association between demographic factors and saving of state sector employees in the Karaveddy Divisional Secretariat. Based on the analysis of the data it is concluded that there is an association between age, civil status, educational qualification and income; and saving of the state sector employees in the Karaveddy Divisional Secretariat. However, author couldn't find any association between gender and family size; and saving. Governmental authorities, banks and financial institutions should consider these findings when they design their saving and investment promotion programs. Developing an economic environment which offers various investment opportunities for households is essential for promoting saving habit among them. Particularly, Governmental authorities and state banks can play a key role in this regard. Since age and civil status of state sector employees have association with their saving, different categories of saving and investment programs can be introduced to attract different age group of state sector employees and these programs should carry certain unique features for each age group. Similarly, separate saving and investment programs may be introduced to married and single employees. In addition, since income has an association with saving of state sector employees, local governmental authorities can introduce various projects to motivate state sector employees to engage in certain part time economic activities in addition to their state sector employment in order to increase their income. These may be in the forms of poultry farming, home gardening and so on. Further, in addition to demographic factors saving depends on other socio-economic factors too. Therefore, future researches in the field of saving can be carried out by including those factors .

\section{Bibiliography:-}

1. Attanasio, O. (1997). Consumption and saving behaviour: modelling recent trends. Fiscal studies, 18(1), 23-47.

2. Bautista, R. M., and Lamberte, M. B. (1990). Comparative Saving behaviour of Rural and Urban Households in the Philippines. Journal of Philippines Development, 17(2), 149-181.

3. Bovenberg, A. L., \& Evans, O. (1990). National and personal saving in the United States: measurement and analysis of recent trends. Staff Papers, 37(3), 636-669.

4. Brata, A. G. (1999). Household Saving Behavior: The case of rural industry in Bantul. Analysis Csis, 28(1), 7586.

5. Browning, M., \& Lusardi, A. (1996). Household saving: Micro theories and micro facts. Journal of Economic literature, 34(4), 1797-1855.

6. Burney, N. A., \& Khan, A. H. (1992). Socio-economic characteristics and household savings: An analysis of the households' saving behaviour in Pakistan. The Pakistan Development Review, 31-48.

7. Demery, D., \& Duck, N. W. (2006). Savings-age profiles in the UK. Journal of Population Economics, 19(3), 521-541.

8. Friedman, M. (1957). The permanent income hypothesis. In A theory of the consumption function . Princeton University Press.

9. Huberman, G., Iyengar, S. S., \& Jiang, W. (2007). Defined contribution pension plans: determinants of participation and contributions rates. Journal of Financial Services Research, 31(1), 1-32.

10. Jamal, N., Hanif, M., \& Mushtaq, M. (2014). Interval Regression Model for Family Income and Saving. World Applied Sciences Journal, 32(11), 2276-2284.

11. Keynes, J. (1936). The General Theory of Employment, Interest, and Money. London: MacMillan.

12. Khalek, T. A., Arestoff, F., De-Freitas, N. E., and Mage, S. (2009). A Micro-econometric analysis of Households Saving determinants in Morocco. 1-18. 
13. Lahiri, A. K. (1989). Dynamics of Asian savings: the role of growth and age structure. Staff Papers, 36(1), 228261.Schrooten, M., \& Stephan, S. (2005). Private savings and transition. Economics of Transition, 13(2), 287309.

14. Li, J., Montalto, C. P., \& Geistfeld, L. V. (1996). Determinants of financial adequacy for retirement. Journal of Financial Counseling and planning, 7, 39.

15. Loayza, N., Schmidt-Hebbel, K., \& Servén, L. (2000). What drives private saving across the world?. Review of Economics and Statistics, 82(2), 165-181.

16. McConnell, C. R. \& Brue, S. L. (1999). Economics, principles, problems, and policies (14th ed.). New York: McGraw-Hill Companies Inc.

17. Modigliani, F., \& Brumberg, R. (1954). Utility analysis and the consumption function: An interpretation of cross-section data. Franco Modigliani, 1.

18. Muradoglu, G., \& Taskin, F. (1996). Differences in household savings behavior: evidence from industrial and developing countries. Developing Economies, 34, 138-153.

19. Newman, C., Tarp, F., Broeck, K. V. D., Quang, C. T., and Khai, L. D. (2008). Household Savings in Vietnam: Insights from a 2006 rural household survey. Vietnam Economic Management Review, 34(1), 1-8.

20. Nurkse, R. (1953). Problems of capital formation in underdeveloped countries. Oxford: Blackwell.

21. Schmidt-Hebbel, K., Serven, L., \& Solimano, A. (1996). Saving and investment: paradigms, puzzles, policies. The World Bank Research Observer, 11(1), 87-117.

22. Schmidt-Hebbel, K., Webb, S. B., \& Corsetti, G. (1992). Household saving in developing countries: first crosscountry evidence. The World Bank Economic Review, 6(3), 529-547.

23. Schrooten, M., \& Stephan, S. (2005). Private savings and transition. Economics of Transition, 13(2), 287-309.

24. Solow, R. M. (1956). A contribution to the theory of economic growth. The quarterly journal of economics, $65-$ 94.

25. ur Rehman, H., Faridi, M. Z., \& Bashir, F. (2010). Households saving behaviour in pakistan: A case of multan district. Pakistan Journal of Social Sciences (PJSS), 30(1), 17-29.

26. Zhang, J., Zhang, J., \& Lee, R. (2003). Rising longevity, education, savings, and growth. Journal of Development Economics, 70(1), 83-101. 